\title{
MODEL PEMBELAJARAN PORTOFOLIO DAN HASIL PENILAIAN DALAM BIDANG STUDI PENDIDIKAN KEWARGANEGARAAN SISWA KELAS V SEKOLAH DASAR PANGGANG GIRIHARJO KECAMATAN PANGGANG GUNUNG KIDUL
}

\author{
Oleh: \\ Sukoco \\ Universitas Cokroaminoto Yogyakarta
}

Dalam penelitian ini bertujuan untuk mengetahui Model pembelajaran portofolio dan hasil penilaian dalam bidang studi Pendidikan Kewarganegaraan siswa kelas V SD Negeri Panggang I Giriharjo Gunung Kidul. Dalam penelitian ini yang menjadi subyek adalah guru dan siswa kelas V SD Negeri Panggang I Giriharjo Gunung Kidul. Untuk mendapatkan data digunakan metode wawancara obervasi dan dokumentasi. Sedangkan untuk menganalisa data digunakan analisa data kualitatif dan kuantitatif. Analisa data kuantitatif digunakan untuk menganilasa data yang berupa keterangan-keterangan, dan analisis data kuantitatif digunakan untuk menganalisa data perubahan jumlah atau frekuensi dari hasil pekerjaan siswa, selanjutnya dianalisa dengan rumus presentase. Kesimpulan dari penelitian ini adalah bahwa pembelajaran dan penilaian portopolio bagi guru merupakan model yanh efektif, tidak membebani dan dapat dilaksanakan secara baik. Bagi siswa merasa diperhatikan oleh guru dan hubungan guru dengan siswa terjalin secara baik.

Kata Kunci: Model, Portofolio, Penilaian, PKn, SD

\section{Pendahuluan}

Peningkatan mutu pendidikan diperlukan pola piker yang digunakan sebagai landasan pelakana kurikulum. Proses belajar mengajar terfokus pada siswa, selain fokus pada siswa pola piker pembelajaran perlu diubah dari sekedar memahami konsep dan prisip keilmuan, siswa juga harus memiliki kemampuan untuk berbuat sesuatu dengan menggunakan konsep dan prinsip keilmuan yang telah dikuasai. Dalam pilar pembelajaran yang dinyatakan UNESCO, selain terjadi "learning to-know" (pembelajaran untuk tahu), juga harus trjadi "learning to-do" (pembelajaran untuk berbuat), dan bahkan dituntut untuk sampai pada "learning to be" (pembelajaran untuk membangun jati diri yang kokoh), dan "learning to live together" (pembelajaran untuk hidup bersama secara harmonis). Dalam pilar tersebut erat kaitannya dengan system penilaian, karena penilaian merupakan bagian penting dalam proses belajar mengajar. 
Penilaian dilakukan untuk mengukur tingkat ketercapaian tujuan pembelajaran, serta kekuatan dan kelemahan yang ada pada proses pembelajaran yang berlangsung. Hasil penilaian ini dapat digunakan untuk memperbvaiki mutu pembelajaran selanjutnya. Upaya peningkatan mutu pembelajaran merupakan bagian terpadu dan peningkatan kreativitas belajar siswa. Salah satu factor yang dapat mempengaruhi keberhasilan siswa adalah profesionalitas yang dimiliki oleh guru dalam mengelola kelas. Peranan pentingnya guru sebgai pengelola kelas akan mengorganisasikan sumber belajar dan menghubungkan sumber belajar sehingga dapat mewujudkan tujuan pembelajaran dengan cara efektif, efisien dan ekonomis. Untuk melakukan peningkatan pembelajaran ada beberapa unsur antara lain:

1. Kesiapan

2. Motivasi

3. Persepsi

4. Tujuan

5. Perbedaan individual

6. Transfer dan retensi

7. Belajar kognitif

8. Belajar afektif

9. Belajar psikomotorik

10. Evaluasi (Paulina panen, 1999: 11)

Pembelajaran pendidikan pancasila dan kewarganegaraan penilaiannya harus dilaksakan secara berkala, berkesinambungan, menaksir sesuatu secara menyeluruh yang meliputi bakat, penyesuaian personal dan social, sikap dan minatnya. Namun dalam praktek secara langsung guru lebih banyak mengukur dan menilai hasil belajar siswa hanya berdasarkan pada prestasi akademik saja, tidak menjangkau seluruh aspek-aspek tersebut di atas. Salah satu bentuk penilaian yang dipandang dapat dilaksanakan secara berkala, berkesinambungan, menaksir secara menyeluruh yang meliputi bakat, penyesuaian personal dan sosial, siakp dan minatnya adalah model penilaian berbasis portofolio.

Adapun keadaan siswa sekolah Dasar Negeri Panggang I Gunung Kidul menurut data hasil sekolah sebagaian besar berasal dari keluarga yang berlatar pendidikan rendah dan ekonomi lemah, sehingga orang tua tidka mempunyai waktu yang banyak untuk membimbing putra- 
putriya. Bahkan ada juga siswa-siswi kalau pulang sekolah harus membantu orang tuanya mencari nafkah hingga malam hari, sehangga siswa tadi sering tidak mengerjakan tugas sekolah. Dengan adanya penilaian portofolio siswa diharuskan mengerjakan tugas rumah dan ulangan dengan sungguh-sungguh.

\section{Landasan Teoritis}

Istilah pembelajaran merupakan istilah baru yang dipergunakan untuk menunjukkan kegiatan guru dan siswa. Sebelumnya menggunakan istilah proses belajar mengajar dan pengajaran. Pembelajaran adalah "serangkaian kegiatan yang dirancang agar memungkinkan terjadinya proses belajar pada siswa" (paulina panen, 1995;5) tidak dipilihnya kata pengajaran karena kata pengajaran, hanya membatasi diri pada hubungan tatap muka guru-siswa didalam kelas. Dalam istilah pembelajaran, interaksi siswa tidak dibatasi oleh kehadiran guru secara fisik. Siswa dapat belajar melalui ajar cetak, program radio, program televise ataupun media lain. Namun demikian guru tetap memainkan peranan penting dalam merancang setiap kegiatan pembelajaran. Pengajaran merupakan salah satu kegiatan pembelajaran. Pengertian diatas dapat kita kitahui bahwa pembelajaran sebagai pengorganisasian atau pengaturan suatu kondisi lingkungan yang sebaik-baiknya yang memungkinkan terjadinya proses belajar pada siswa.

\section{Pembelajaran memiliki beberapa ciri antara lain:}

1. Unsur kesengajaan dari pihak luar individu yang melakukan proses belajar tetapi perlu diingat bahwa semua proses belajar terjadi dengan sengaja

2. Adanya interaksi
a) Interaksi guru dengan siswa
b) Interaksi siswa dengan siswa
c) Interaksi siswa dengan guru
d) Interaksi siswa dengan lingkungan

3. Adanya komponen yang saling berkaitan
a) Tujuan
b) Materi
c) Kegiatan 
d) Evaluasi

\section{Metode Penelitian}

Penelitian dilakukan dengan mengambil lokasi di SD Negeri Panggang 1 Giriharjo Gunung Kidul, adapun waktu penelitian dilaksanakan pada semester ganjil yaitu bulan September sampai dengan November 2011. Dalam penelitian ini yang menjadi subyek penelitian antara lain guru SD Negeri Panggang I Giriharjo Gunung Kidul dan siswa SD Negeri Panggang I Giriharjo Gunung Kidul, dalam pengumpulan data diperlukan data yang dapat dipertanggung jawabkan kebenarannya sesuai dengan yang akan diteliti,maka penulis menggunakan beberapa tahapan metode antara lain,

1. Metode interview (wawancara)

2. Metode observasi

3. Metode dokumentasi

Dalam metode analisa data yang dipakai menggunakan analisa data kualitatif dan analisa data kuantitatif.

\section{Pembahasan}

1. Tempat Penelitian

Tempat penelitian di sekolah dasar Negri I Giriharjo Panggang Gunung Kidul

2. keadaan Siswa

\begin{tabular}{|c|c|c|c|}
\hline Kelas & Jumlah laki-laki & $\begin{array}{c}\text { Jumlah } \\
\text { perempuan }\end{array}$ & $\begin{array}{c}\text { Jumlah } \\
\text { keseluruhan }\end{array}$ \\
\hline I & 17 & 11 & 28 \\
\hline II & 9 & 9 & 18 \\
\hline III & 17 & 13 & 30 \\
\hline IV & 15 & 13 & 28 \\
\hline V & 13 & 18 & 36 \\
\hline VI & 11 & 8 & 19 \\
\hline Jumlah & 82 & 75 & 159 \\
\hline
\end{tabular}


3. Keadaan Guru

\begin{tabular}{|c|l|l|l|}
\hline No. & Nama/ Tugas Mengajar & Pendidikan & Keterangan \\
\hline 1. & Regu Riyanto, S.Pd. & Sarjana & Kepala Sekolah \\
2. & Suyono, S.Pd. & Sarjana & Guru Kelas V \\
3. & Mulyanti, S.Pd. & Sarjana & Guru Kelas I \\
4. & Tri Kundari, S.Pd. & Sarjana & Guru Kelas IV \\
5. & Sutriyono, S.Pd. & Sarjana & Guru Kelas VI \\
6. & Sukoco & Sarjana & Guru Kelas III \\
7. & Suyatno, S.Pd. & Sarjana & Guru Kelas II \\
8. & Tusilah, S.Pd. & Sarjana & Guru Penjas \\
9. & Erliani Zuliyati, S.Ag. & Sarjana & Guru PAI \\
\hline
\end{tabular}

\begin{tabular}{|c|l|l|l|}
\hline No & Nama & Pendidikan & Keterangan \\
\hline 1. & Wari Ismawati & SMA & Perpustakaan \\
2. & Parjiyo, S.Pd. & Sarjana & Peg. Administrasi \\
3. & Suhardi & SMA & Penjaga \\
\hline
\end{tabular}

Penilaian Portofolio Pada Pendidikan Kewarganegaraan SD Negeri I Giriharjo Panggang Gunung Kidul

1. Pelaksanaan Portofolio yang materi pokok bahasan dilaksanakan pada minggu kesatu sampai minggu keempat. Adapun pelaksanaannya diuraikan sebagai berikut:

a. Untuk minggu pertama setelah proses pembelajaran siswa diberi tugas mengerjakan soal dari buku lembar kegiatan siswa (LKS).

b. Untuk minggu kedua pada akhir proses pembelajaran siswa diberi tugas untuk mengerjakan soal pekerjaan rumah (PR I) yang dibuat oleh guru.

c. Untuk minggu ketiga pada akhir proses pembelajaran siswa diberi tugas untuk mengerjakan soal pekerjaan rumah (PR II) yang dibuat oleh guru.

d. Untuk minggu keempat diadakan ulangan harian (UH) soal dibuat oleh guru.

Pada awal minggu pertama siswa diberi tugas untuk mengerjakan soal pada buku LKS. Melalui kegiatan tugas mengerjakan soal pada buku LKS merupakan upaya untuk melatih siswa agar dapat memahami materi dan berlatih bagaimana menjawab pertanyaan-pertanyaan. Pembahasan soal dilakukan secara klasikal, guru membantu siswa dalam menjawab pertanyaanpertanyaan di LKS. Tugas pekerjaan rumah untuk siswa sudah dapat diselesaikan siswa secara individu sesuai waktu yang telah ditentukan. Guru memeriksa hasil dari pekerjaan rumah tersebut dan mengadakan penilaian. Bagi siswa yang masih memperoleh nilai yang kurang baik 
(<10) lembar pekerjaan siswa dikembalikan lagi kepada guru untuk dinilai kembali dan selanjutnya disimpan oleh siswa dalam map masing-masing.

2. Pendapat siswa mengenai pelaksanaan penilaian portofolio

a. Tugas pekerjaan rumah pertama dan kedua

Hasil analisa mengenai pendapat siswa terhadap pelaksanaan portofolio untuk kelas $\mathrm{V}$ yang berupa pekerjaan rumah ditampilkan pada table berikut:

\begin{tabular}{|l|l|l|l|l|}
\hline \multicolumn{1}{|c|}{ NO } & \multicolumn{1}{|c|}{ JENIS PERTANYAAN } & \multicolumn{1}{c|}{ PENDAPAT SISWA } & \multicolumn{1}{c|}{$\%$} \\
\hline 1. & Daya Tarik & - Sangat menarik & 16 & 44,44 \\
& & - Cukup menarik & 20 & 55,55 \\
\hline 2. & Peningkatan Pemahaman & - Sangat setuju & 7 & 19,44 \\
& & - Setuju & 19 & 80,55 \\
\hline 3. & Peningkatan Ketrampilan & - Sangat setuju & 6 & 16,66 \\
& & - Setuju & 19 & 83,33 \\
\hline 4. & Jumlah Soal Membebani & - Tidak membebani & 30 & 83,33 \\
& & - Sangat tidak membebani & 6 & 16,66 \\
\hline 5. & Tingkat Keahlian & - Sulit & 3 & 8,33 \\
& & - Tidak sulit & 28 & 77,77 \\
& & - Sangat tidak sulit & 5 & 13,88 \\
\hline
\end{tabular}

Berdasarkan tebel di atas mengenai pendapat siswa terhadap penilaian portofolio bentuk pekerjaan rumah menunjukkan bahwa sebagian besar dari siswa berpendapat bahwa portofolio menarik (sangat menarik 44,44\%, cukup menarik 55,55\%) . meningkatkan pemahaman (sangat setuju 19,44\%, 80,55\%). Meningkatkan ketrampilan (sangat setuju 16,66\%, setuju 83,33\%). Jumlah soal membebani $16,66 \%$ ). Tingkat kesulitan (sulit 8,33\% , tidak sulit 77,77\% , sangat tidak sulit 13,88\%).

b. Ulangan harian

Hasil analisis mengenai pendapat siswa terhadap pelaksanaan portofolio yang berupa ulangan harian ditampilkan pada table berikut: 


\begin{tabular}{|c|c|c|c|c|}
\hline $\mathrm{NO}$ & JENIS PERTANYAAN & PENDAPAT SISWA & $\mathrm{F}$ & $\%$ \\
\hline 1. & Daya tarik & $\begin{array}{l}\text { - Sangat menarik } \\
\text { - Cukup menarik }\end{array}$ & $\begin{array}{l}10 \\
26\end{array}$ & $\begin{array}{l}27,77 \\
72,22\end{array}$ \\
\hline 2. & Peningkatan pemahaman & $\begin{array}{l}\text { - Sangat setuju } \\
\text { - Setuju }\end{array}$ & $\begin{array}{l}6 \\
30\end{array}$ & $\begin{array}{l}16,66 \\
83,33\end{array}$ \\
\hline 3. & Peningkatan ketrampilan & $\begin{array}{l}\text { - Sangat setuju } \\
\text { - Setuju }\end{array}$ & $\begin{array}{l}5 \\
31\end{array}$ & $\begin{array}{l}44,11 \\
55,88\end{array}$ \\
\hline 4. & Jumlah soal membebani & $\begin{array}{l}\text { - } \text { Membebani } \\
\text { - } \text { Tidak membebani } \\
\text { - Sangat tidak } \\
\text { membebani }\end{array}$ & $\begin{array}{l}1 \\
31 \\
4\end{array}$ & $\begin{array}{l}2,77 \\
86,11 \\
11,11\end{array}$ \\
\hline 5. & Tingkat kesulitan & $\begin{array}{l}\text { - Sulit } \\
\text { - } \text { Tidak sulit } \\
\text { - } \text { Sangat tidak sulit }\end{array}$ & $\begin{array}{l}1 \\
28 \\
7\end{array}$ & $\begin{array}{l}2,77 \\
77,77 \\
19,41\end{array}$ \\
\hline
\end{tabular}

3. Pendapat guru mengenai pelaksanaan penilaian portofolio

Berdasarkan hasil wawancara tanggal 12 september 2011 dengan guru kelas V SD Negeri

Panggang I Giriharjo Gunung Kidul:

Nama $\quad$ : Suyono, S.Pd.

NIP $\quad: 196905131991121001$

Pertanyaan:

1. Bagaimana pendapat bapak tentang pelaksanaan penilaian portofolio ditinjau dari segi efektifitasnya?

2. Bagaimana pendapat bapak mengenai beban guru dengan pelaksanaan penilaian portofolio?

3. Bagaimana pendapat bapak mengenai realisasi penilaian portofolio? Jawab:

1. Penilaian portofolio merupakan model penilaian yang efektif karena dapat untuk mengetahui kinerja siswa secara berkesinambungan.

2. Guru tidak terbebani disamping itu guru bias lebih memahami keadaan atau kemampuan anak didiknya. 
3. Penilaian portofolio dapat dilaksanakan secara baik bahkan hubungan guru dengan murid bias terjalin dengan lebih baik.

\section{Hasil Penilaian Portofolio}

1. Hasil penelitian portofolio tahap pertama

Hasil analisis mengenai kegiatan siswa saat melaksanakan tugas LKS pada umumnya semua siswa berupaya melaksanakan dengan sungguh-sungguh. Namun masih ada beberapa siswa yang belum dapat secara lancer mengerjakan soal dalam LKS. Hal tersebut terjadi karena siswa masih kurang memahami isi dan maksud dari pertanyaan.

Setelah guru memberikan penjelasan seperlunya tentang maksud dari soal yang dianggap sulit, siswa dapat menerimanya dan dapat menjawab soal tersebut dengan benar. Melalui caracara menjawab soal seperti ini diharapkan siswa dapat mengerjakan soal pekerjaan rumah secara baik dirumah.

2. Hasil penelitian tahap kedua

Hasil penilaian tahap kedua siswa mengerjakan tugas rumah yang dibuat oleh guru, untuk kegiatan ini siswa tersebut dikerjakan, sebelumnya diadakan kesepakatan antara siswa dengan guru. Kesepakatan mengenai jenis tugas yang harus dikerjakan dan waktu penyelesaian tugas untuk diserahkan kembali setelah selesai dikerjakan siswa. Selain itu guru dan siswa mengadakan kesepakatan agar tugas yang sudah selesai dikerjakan akan diperiksa oleh guru dan dikembalikan lagi untuk diperbaiki kembali bagi siswa yang memperoleh nilai <10. Hasil penilaian pekerjaan rumah sebelum perbaikan untuk siswa yang belum memperoleh nilai 10 adalah 27,77\%, nilai 9 adalah 25\%, nilai 8 adalah 19,44\%, nilai 7 adalah $11,11 \%$, nilai 6 adalah 16,66\%. Hasil pekerjaan rumah yang nilainya <10 dikembalikan untuk diperbaiki sebanyak 72,23\%. Setelah diadakan perbaikan oleh siswa hasilnya yaitu nilai 8 adalah 13,88\%, nilai 9 adalah $11,11 \%$ dan nilai 10 adalah $75 \%$.

3. Hasil penilaian portofolio tahap ketiga

Hasil penilaian pekerjaan rumah kedua sebelum perbaikan untuk siswa yang memperoleh nilai 10 adalah 33,33\%, nilai 8 adalah 19,44\%, nilai 7 adalah 19,44\% dan nilai 6 adalah 2,77\%. Hasil pekerjaan rumah <10 dikembalikan untuk diperbaiki sebanyak 66,67\%. Setelah diadakan perbaikan hasilnya yaitu nilai 8 adalah 5,55\% nilai 9 adalah $13,88 \%$ dan nilai 10 adalah 80,55\%. 
4. Hasil penilaian portofolio tahap keempat

Hasil ulangan harian memperoleh hasil untuk nilai paling bawah adalah 7 sebanyak $13,88 \%$ dan paling atas adalah 10 sebanyak 27,77\%. Hasil ulangan harian yang nilainya $<10$ dikembalikan untuk diperbaiki sebanyak $72,23 \%$. Setelah ada perbaikan memperoleh nilai paling bawah 7,5 sebanyak 2,77\% dan nilai 10 sebanyak 69,44\%.

5. Hasil rata-rata persentase pekerjaan rumah dan ulangan harian

Hasil persentase rata-rata mengenai pekerjaan rumah dan ulangan harian bagi siswa yang memperoleh nilai <10 sebagai berikut:

a. Pekerjaan Rumah. Sebelum perbaikan yang memperoleh nilai <10 adalah 69,45\% dan sesudah perbaikan adalah $22,21 \%$.

b. Ulangan Harian. Sebelum perbaikan yang memperoleh nilai $<10$ adalah $72,23 \%$ dan sesudah perbaikan adalah $30,55 \%$

Hal ini disebabkan karena sebelum perbaikan pada umumnya anak kurang memahami maksud dari soal-soal, dan sesudah diadakan penjelaan seperlunya, anak mengerjakan perbaikan dengan lebih baik.

\section{Kesimpulan}

Hasil penelitian pelaksanaan penilaian portofolio pada pendidikan pancasila dan kewarganegaraan kelas V SD Negeri Giriharjo Panggang I Gunung Kidul disimpulkan sebagai berikut:

1. Model penilaian pembelajaran pendidikan pancasila dan kewarganegaraan melalui portofolio terdiri dari dua tugas yaitu pekerjaan rumah dan ulangan harian, dua hal tersebut dapat dilaksanakan sesuai dengan kelas yang dipakai sebagai subyek penelitian. Bagi guru penilaian portofolio merupakan suatu model yang efektif, tidak merasa membebani dan dapat dilaksanakan secara baik, sedangkan bagi siswa merasa diperhatikan oleh guru dan hubungan antara guru dengan siswa terjalin secara baik.

2. Hasil pelaksanaan penilaian portofolio menunjukkan adanya peningkatan jumlah nilai siswa yang memperoleh nilai 10, baik sebelum siswa mengadakan perbaikan maupun setelah diadakan perbaikan oleh siswa. Tugas rumah maupun ulangan harian. Hasil rata-rata untuk pekerjaan rumah yang memperoleh nilai <10 sebelum perbaikan 69,45\% dan sesudah 
perbaikan $22,21 \%$. Sedangkan untuk ulangan harian yang memperoleh nilai $<10$ sebelum, perbaikan $72,23 \%$ dan sesudah perbaikan $30,55 \%$.

\section{Daftar Pustaka}

Paulina Panen, 1999, Belajar dan Pembelajaran I, Jakarta: Universitas Terbuka.

Sardinian A.M., 1989, Interaksi dan Motivasi Belajar Mengajar, Jakarta: Rajawali.

Suparwoto dkk, 1983, Hierarchi Tujuan Pendidikan (Modul 3), IKIP Yogyakarta. 